\title{
Correction to: Current Approach to Successful Liberation from Renal Replacement Therapy in Critically III Patients with Severe Acute Kidney Injury: The Quest for Biomarkers Continues
}

\author{
Helmut Schiffl ${ }^{1}$. Susanne M. Lang ${ }^{2}$
}

Accepted: 7 May 2021 / Published online: 3 June 2021

(c) The Author(s) 2021

\section{Correction to: Molecular Diagnosis \& Therapy (2021) 25:1-8 https://doi.org/10.1007/s40291-020-00498-z}

The article Current Approach to Successful Liberation from Renal Replacement Therapy in Critically Ill Patients with Severe Acute Kidney Injury: The Quest for Biomarkers Continues written by Helmut Schiffl, Susanne M. Lang was originally published Online First without Open Access. After publication in volume 25, issue 1 the author decided to opt for Open Choice and to make the article an Open Access publication. Therefore, the copyright of the article has been changed to $\odot$ The Author(s) and the article is forthwith distributed under the terms of the Creative Commons Attribution.
Funding Open Access funding provided by Projekt DEAL.

Open Access This article is licensed under a Creative Commons Attribution 4.0 International License, which permits use, sharing, adaptation, distribution and reproduction in any medium or format, as long as you give appropriate credit to the original author(s) and the source, provide a link to the Creative Commons licence, and indicate if changes were made. The images or other third party material in this article are included in the article's Creative Commons licence, unless indicated otherwise in a credit line to the material. If material is not included in the article's Creative Commons licence and your intended use is not permitted by statutory regulation or exceeds the permitted use, you will need to obtain permission directly from the copyright holder. To view a copy of this licence, visit http://creativecommons.org/licenses/by/4.0/.

The original article can be found online at https://doi.org/10.1007/ s40291-020-00498-z.

Helmut Schiffl

h-schiffl@t-online.de

1 Department of Internal Medicine IV, University Hospital LMU Munich, Munich, Germany

2 Klinik für Innere Medizin II, Universitätsklinikum Jena, Jena, Germany 